\title{
Anti-Reovirus Antibody
}

National Cancer Institute

\section{Source}

National Cancer Institute. Anti-Reovirus Antibody. NCI Thesaurus. Code C123805.

An antibody produced in response to exposure to reovirus. 